\title{
頭頸部癌の遠隔転移に対する治療効果
}

\author{
平野滋・北村 溥之・宮田 耕志 \\ 金子 賢一・安里 亮

\section{Therapeutic Results for Distant Metastases of Head and Neck Cancers}

\author{
Shigeru Hirano, Hiroyuki Kitamura, Koji Miyata, \\ Ken-ichi Kaneko and Ryo Asato
}

(Tenri Hospital)

Therapeutic results for 46 patients with distant metastases of head and neck cancers other than thyroid cancer, treated at Tenri hospital from 1975 to 1992 , were evaluated. Of 57 sites of metastases studied, 30 were in the lung, 11 the liver and 11 the bone. Chemotherapy, radiotherapy and surgery were performed singly or in combination and the results for each site of metastases was analysed. For lung metastases, radiotherapy or surgery, if possible, is considered effective in improving the prognosis. The prognosis for liver metastases was quite poor, but transarterial infusion into the hapatic artery was expected to prolong the survival period. Radiotherapy for bone metastases was quite effective, while chemotherapy had little effect. Active therapy for distant metastases was expected to improve the quality of life.

Key words: distant metastases, head and neck cancer, therapy

はじめに

頭頸部癌の遠隔転移は頻度が低く，また予後 不良の例が多いため積極的な治療を断念する傾 向があり，治療成績の報告も極めて少ない。転 移癌に执いても，その部位によって治療効果が 大きく異なるので，今後の治療の指針とするた め, 当院における頭頸部癌の遠隔転移例につき 部位別に治療効果を調べ報告する.

\section{対 象}

1975～1992年の間に天理よろづ相談所病院耳 鼻咽喉科で経過観察を行った，甲状腺癌を除く 頭頸部癌遠隔転移症例46例(転移延べ部位数57
例）を対象とした。性別は男性29例，女性17例 で, 年龄は $28 \sim 77$ 歳, 平均 56 歳であった. 原発 宩は上咽頭が最多で, 以下, 口腔, 喉頭, 鼻副 鼻腔の順であった（表 1)。組織型は扁平上皮癌 が最多で，以下は表 2 の如くであった。転移部 位の延べ例数は, 肺30例, 肝11例, 骨11例であ った。また，これを化学療法, 放射線療法, 手 術を単独または併用で行った治療群と, 経過観 察の久の非治療群に分けると, 治療群は肺23例, 肝 8 例, 骨11例であった(表 3 )。治療効果の判 定は日本頭頸部腫瘍学会編頭頸部癌取扱い規 約1)の判定基準に基ついて行った. 尚, 脳, 脾, 
縦隔転移例は, 症例数が少なく今回の検討から 除外した.

\section{結果}

1. 転移発見からの生存期間と生存率(表 4) 遠隔転移が発見されてからの生存期間は, 最 短 1 力月から最長 60 力月に及んだが, 中央値は 6 カ月であった。治療群に批いては， 1 年生存

表 1 原発巣の部位

\begin{tabular}{cc}
\hline \hline 上咽頭 & $15($ 例 $)$ \\
口 腔 & 9 \\
喉 頭 & 6 \\
鼻副鼻腔 & 6 \\
大唾液腺 & 4 \\
中咽頭 & 3 \\
下咽頭 & 2 \\
頸部食道 & 1 \\
\hline 計 & 46
\end{tabular}

表 2 組織型

\begin{tabular}{cc}
\hline \hline 扁平上皮癌 & $26($ 例 $)$ \\
未分化癌 & 6 \\
リンパ上皮腫 & 3 \\
悪性黒色腫 & 3 \\
腺様豊胞癌 & 2 \\
粘表皮癌 & 2 \\
腺 癌 & 1 \\
腺房細胞腫 & 1 \\
腺扁平上皮癌 & 1 \\
線維肉腫 & 1 \\
\hline \multicolumn{1}{c}{ 計 } & 46
\end{tabular}

表 3 転移部位の延べ例数

\begin{tabular}{clc}
\hline \hline & & 治療群 \\
\hline 肺 & 30 (例) & $23($ 例 $)$ \\
肝 & 11 & 8 \\
骨 & 11 & 11 \\
脳 & 3 & 2 \\
脾 & 1 & 1 \\
縦隔 & 1 & 1 \\
\hline 計 & 57 & 46
\end{tabular}

率が $23.9 \%$ であったが， 2 年生存率は $6.5 \%$ に 激減し, 5 年生存例は僅かに腺様襄胞癌の肺転 移例の 1 例のみであった。一方, 非治療群には 1 年生存例すらなかった。

2. 転移部位別治療効果と生存期間

転移部位別治療効果は, 奏効率, $\mathrm{CR}$ 率がそ れぞれ肺(手術例 2 例を除く)で43\%，0\%，肝 で25\%，0\%，骨で46\%，18\%であり，肝転移 に対する効果が特に劣っていた(表 5 )。全体で は奏効率 $39 \%, \mathrm{CR}$ 率 $5 \%$ であった。転移発見 からの生存期間を治療群でみると, 肺 $2 \sim 60$ 力 月 (中央值10力月), 肝 $1 \sim 13$ 力月 (中央値 3 力 月), 骨 $3 \sim 16$ 力月 (中央値 7 力月) と肝転移例 で短い傾向がみられた(表 6 ).

3. 治療法別にみた治療効果

1) 肺転移例について(表 7 )

化学療法のみの群では奏効率 $38 \%$, 生存期間 が $2 \sim 60$ 力月 (中央値 7 力月)であるのに対し,

表 4 治療群と非治療群でみた粗生存率 (\%)

\begin{tabular}{c|c|c|c}
\hline \hline $\begin{array}{c}\text { 転移発見からの } \\
\text { 生存期間 }\end{array}$ & 治療群 & 非治療群 & 全体 \\
\hline 1 年 & 23.9 & 0 & 19.3 \\
\hline 2 年 & 6.5 & 0 & 5.3 \\
\hline 3 年 & 4.5 & 0 & 3.5 \\
\hline 4 年 & 4.5 & 0 & 3.5 \\
\hline 5 年 & 2.2 & 0 & 1.8
\end{tabular}

表 5 転移部位別治療効果

\begin{tabular}{c|c|c|c|c|c|c|c}
\hline \hline 部位 & $\mathrm{CR}$ & $\mathrm{PR}$ & $\mathrm{NC}$ & $\mathrm{PD}$ & 計 & 奏効率 $(\%)$ & $\mathrm{CR}$ 率 $(\%)$ \\
\hline 肺 & 0 & 9 & 8 & 4 & $21^{*}$ & 43 & 0 \\
\hline 肝 & 0 & 2 & 4 & 2 & 8 & 25 & 0 \\
\hline 骨 & 2 & 3 & 2 & 4 & 11 & 46 & 18 \\
\hline 脳 & 0 & 0 & 2 & 0 & 2 & 0 & 0 \\
\hline 脾 & 0 & 0 & 1 & 0 & 1 & 0 & 0 \\
\hline 縦隔 & 0 & 1 & 0 & 0 & 1 & 100 & 0 \\
\hline 計 & 2 & 15 & 17 & 10 & 44 & 39 & 5 \\
\end{tabular}

*手術例 2 例を除く 
放射線併用群では奏効率 $67 \%$ ，生存期間 $10 〜 50$ カ月 (中央值11カ月) と比較的良好な結果であっ た. 手術施行例 2 例の生存期間は 6 カ月と 17 カ
月で㐫った，放射線療法と気管支動脈動注療法 そより quality of life (QOL) の向上を得た 1 症 例を提示する。

表 6 転移部位別にみた転移発見からの生存期間(月数)

\begin{tabular}{|c|c|c|c|}
\hline 部位 & 治 療 群 & 非治療群 & 全 \\
\hline 肺 & $2 \sim 60(10)$ & $1 \sim 10(4)$ & $1 \sim 60(7)$ \\
\hline 肝 & $1 \sim 13$ & $5 \sim 10(6)$ & $1 \sim 13(5)$ \\
\hline 骨 & $3 \sim 16 \quad(7)$ & & $3 \sim 16(7)$ \\
\hline 脳 & 2,31 & 6 & $2 \sim 31(6)$ \\
\hline 脾 & 2 & & 2 \\
\hline 縱隔 & 7 & & 7 \\
\hline 全体 & $1 \sim 60$ 力月 $(6$ 力月 $)$ & $1 \sim 10$ 力月（ 6 力月） & $1 \sim 60$ カ月 ( 6 力月) \\
\hline
\end{tabular}

表 7 肺転移例の治療法別治療効果と転移発見からの生存期間(月数)

\begin{tabular}{l|c|c|c|c|c|c}
\hline \hline & $\mathrm{CR}$ & $\mathrm{PR}$ & $\mathrm{NC}$ & $\mathrm{PD}$ & 奏効率(\%) & 生存期間 \\
\hline 化学療法のみ & 0 & 6 & 7 & 3 & 38 & $2 \sim 60 \quad(7)$ \\
\hline 放射線のみ & 0 & 1 & 0 & 1 & 50 & $4 \sim 8 \quad(6)$ \\
\hline \begin{tabular}{l} 
化学療法+放射線 \\
\hline 手術+放射線
\end{tabular} & 0 & 2 & 1 & 0 & 67 & $10 \sim 50(11)$ \\
\hline $\begin{array}{l}\text { 手術+放射線 } \\
\text { 十化学療法 }\end{array}$
\end{tabular}

（）内は中央値

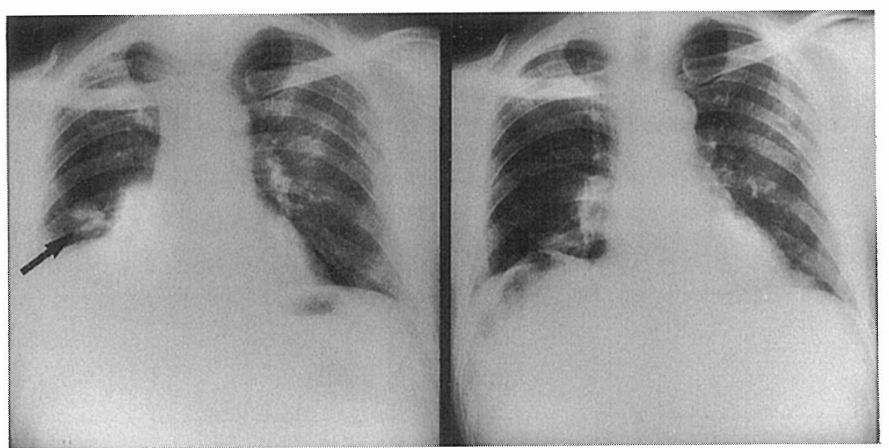

図 1 （左）気管支動脈動注 2 日前. 右下肺野の矢印の部分に転移 巣を認める。

（右）気管支動脈動注 12 日後. 転移栄の消失を認める. 
症例：53歳，男性.

右耳下腺腺房細胞腫の肺転移に対し， CDDP の気管支動脈動注と $54 \mathrm{~Gy}$ の放射線療 法を施行したところ，転移巣は縮小し，転移発 見より 4 年間生存し得た。転帰は局所再発死し たが，転移巣はよく制御され社会復帰も果たせ ていた. 動注療法前後の胸部 $\mathrm{X}$ 線写真を図 1 亿 示す.

2) 肝転移例について(表 8)

経静脈的化学療法群では奏効率 $20 \%$, 生存期 間 $2 \sim 7$ 力月(中央值 3 力月) と極めて不良であ ったが，肝動注群では，奏効率33\%，生存期間 $1 \sim 13$ 力月 (中央値 7 力月) と比較的良好な結果 が得られた。

3) 骨転移例について(表 9)

化学療法のみの群では奏効率 $0 \%$ と極めて不 良であったが，放射線併用群では奏効率 $60 \%$ ， 生存期間 $3 \sim 16$ 力月 (中央値10力月), 放射線の 又の群では奏効率 $50 \%$, 生存期間 $4 \sim 13$ 力月 (中 央值10力月)で，放射線を主体とした治療法で 良好な結果が得られた。

\section{考察}

頭頸部癌の遠隔転移に対する治療成績の報告 は極めて少ない。犬山ら 2 は, 遠隔転移例63例
に化学療法を施行した結果, 奏効率 $33 \%$ (CR 率13\%), 生存期間 $2 \sim 53$ 力月 (中央値10力月) と報告して拈り，また，Kish ら²) は頭頸部再 発癌・転移癌に対する CDDP + $5 \mathrm{FU}$ 療法によ って，転移例で奏効率 $36 \%(\mathrm{CR}$ 率 $9 \%)$, 生存 期間の中央值 6 力月の成績を報告している．今 回の我々の調査では奏効率 $39 \%$ と比較的良好な 成績が得られているが，生存期間の中央值は 6

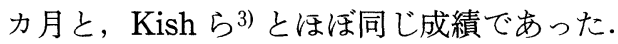

転移部位別の成績を，肺，肝，骨についてみ ると，

1) 肺転移：犬山ら 2) は化学療法を施行した 肺転移46例の奏効率 $35 \%$ を報告しているが，今 回の我々の化学療法のみの群の奏効率は $38 \%$ で, ほ湆同様の結果であった．現在のところ，化学 療法のみでは, これ以上の成績は難しいと思わ れる。一方, 放射線療法群では比較的良好な結 果が得られて扣り, 菅原ら4) は, 主に頭頸部癌, 乳癌などの肺転移例に対する放射線治療成績を 検討し，転移巣が直径 $4 \mathrm{~cm}$ 以下， 4 個以下で 有意に効果があると報告している。すなわち， 放射線療法の適応例は予後良好と考光られる。 手術に関しては, 大森ら5) は, 頭頸部癌肺転移 例32例について，保存的療法群の方が手術群よ

表 8 肝転移例の治療法別治療効果と転移発見からの生存期間(月数)

\begin{tabular}{c|c|c|c|c|c|c|c}
\hline \hline & CR & PR & NC & PD & 奏効率 $(\%)$ & 生存期間 \\
\hline \multicolumn{2}{c|}{ 化学療法 } & 0 & 2 & 4 & 2 & 25 & $1 \sim 13(3)$ \\
\hline & 肝動注 & 0 & 1 & 2 & 0 & 33 & $1 \sim 13(7)$ \\
\cline { 2 - 8 } & 経静脈投与 & 0 & 1 & 2 & 2 & 20 & $2 \sim 7(3)$ \\
\end{tabular}

表 9 骨転移例の治療法別治療効果と転移発見からの生存期間(月数)

\begin{tabular}{l|c|c|c|c|c|c}
\hline & $\mathrm{CR}$ & $\mathrm{PR}$ & $\mathrm{NC}$ & $\mathrm{PD}$ & 奏効率 $(\%)$ & 生存期間 \\
\hline 化学療法のみ & 0 & 0 & 0 & 2 & 0 & 4,5 \\
\hline 化学療法十放射線 & 1 & 2 & 1 & 1 & 60 & $3 \sim 16(10)$ \\
\hline 放射線のみ & 1 & 1 & 1 & 1 & 50 & $4 \sim 13(10)$
\end{tabular}


り好成績であったと述べ，適応の吟味の必要性 を唱えている．今回の対象に拈ける手術例は 2 例の久で，らち 1 例は喉頭癌(扁平上皮癌)の単 発性肺転移に対し肺部分切除を施行し，17力月 間生存し得ており，適応を絞れば延命効果は期 待できると思われた。

2) 肝転移：肝転移例の予後は極めて悪く, 今回の自験例 11 例中 8 例は半年以内に死亡して 抎り, 治療群 8 例でも生存期間の中央值が 3 力 月と不良で, 特に経静脈的化学療法では殆ど効 果が得られていない。これに対し肝動注群では 症例数は少ないが生存期間の延長が得られた.

らち 1 例は上咽頭癌(扁平上皮癌)の多発性肝転 移であったが，CDDP の肝動注の反復で13力 月間生存し得た. 近年, 消化器癌の肝転移に対 する肝動注療法が普及し，その有効性が確認さ れている6)が, 肝動注の利点は, 副作用の軽減 と, 経静脈投与に比べ約 8 倍の増強効果にある とされている7). 従来肝の癌病巣に対する通常 の化学療法の感受性は極めて低く, 動注以外で の効果は殆ど期待できないとさえ言われており， 肝動注を治療の主体にすべきと考えられる。

3 ）骨転移：犬山ら 2) は骨転移に対する化学 療法の奏効率は $0 \%$ で, 現在の化学療法では治 療効果を期待できないとしているが，我々の結 果も同様であった。一方, 今回放射線療法が著 効を示した例が多く, 疼痛緩和にも極めて有効 であり，骨転移に対しては放射線療法を第 1 選 択とすべきと思われた。

近年, 遠隔転移例の QOL の向上は, 選択的 動注療法などを駆使した集学的治療の進歩によ るところが大きく, 症例によっては社会復鹵す ら可能となってきた. 一方, 以前であれば白血 球減少や腹部症状などの副作用のために集中的 な治療が困難であった症例でも，G-CSF（顆粒 球コロニ一刺激因子) 等の優れた薬剤の開発に よって, より強力な化学療法が可能となり, 今 後一層の QOL の向上が期待される.

\section{まとめ}

頭頸部癌遠隔転移症例46例, 転移延べ部位数
57例について転移部位別に治療効果を検討し, 下記の結論を得た。

1. 肺転移例は, 放射線療法や手術適応とな る例では比較的予後が良い。

2. 肝転移例の予後は極めて悪く, 肝動注が 予後の向上に有効と思われた.

3. 骨転移に対する化学療法は期待できず, 放射線療法を主体にすべきと思われた。

4. 遠隔転移に対する積極的な治療によって QOL の向上が期待される.

稿を終えるにあたり, 御校閲, 御指導賜りました 京都大学医学部耳鼻咽喉科学教室本庄 簏教授に深 謝致します。

\section{参考文献}

1）日本頭頸部腫瘍学会編：頭頸部癌取扱い規約 (第二版). 96〜102頁, 1991 .

2) 犬山征夫, 吉田 康, 福田 諭, 他 : 遠隔転移 に関する諸問題 2 .頭頸部癌の遠隔転移に対す る治療成績 -3 ) 化学療法の立場から一. 頭頸 部腫瘍 $17: 42 \sim 46,1991$.

3) Kish JA, Weaver A, Jacobs J, et al : Cisplatin and 5 -fluorouracil in fusion in patients with recurrent and disseminated epidermoid cancer of the head and neck. Cancer $53:$ 1819 1824, 1984.

4）菅原 正，金田浩一：転移性肺癌の放射線療法. 日癌誌 $18: 143 \sim 144,1983$.

5）大森研史, 牧本一男, 越智真理, 他 : 頭頸部悪 性腫瘍の肺転移例についての検討. 耳鼻臨床 82: 703 708, 1989.

6）荒井保明, 木戸長一郎, 遠藤登喜子, 他 : 転移 性肝癌に対する FAM 動注化学療法 (phase II study) 一 preliminary report-. 癌と化学療法 $14: 2327 \sim 2333,1987$.

7）小澤 隆，木村幸三郎，小柳泰久, 他 : ${ }^{99 \mathrm{~m}} \mathrm{Tc}$ 人血清アルブミン (HSA) による肝動注時の first pass effect $の$ 検討. 癌と化学療法 15 : 2479 2483, 1988.

\footnotetext{
/原稿受付: 平成 5 年 3 月 9 日 原稿採択 : 平成 5 年 5 月 6 日 別刷請求先: 平野 滋 干632 天理市三島町 200 天理よろつ”相談所病院耳鼻咽喉科)
} 